\title{
Performance of 'Galia' melon grown under different soil cation ratios
}

\section{Desempenho do melão Gália cultivado sob diferentes relações catiônicas do solo}

\author{
Cristiane Alves de Paiva1*; José Francismar de Medeiros²; José Gustavo Lima de \\ Almeida ${ }^{3}$;Edna Maria Mendes Aroucha ${ }^{4}$
}

\section{Highlights}

Different cation ratios influence the total and marketable fruit weights.

Cation ratios do not influence the final yield.

High $\mathrm{K}$ and $\mathrm{Mg}$ concentrations in soil and water dispense with correction.

\section{Abstract}

The northeast region of Brazil stands out in the production and export of melon. In this region, where this crop is mostly grown, part of the soil is of limestone origin, as is the irrigation water used. Over successive cultivations, these conditions can lead to soil alkalinization due to the accumulation of basic cations of the exchange complex, such as $\mathrm{Ca}, \mathrm{Mg}, \mathrm{K}$ and $\mathrm{Na}$, in soils that are already rich in bases, thus influencing nutrient availability and, consequently, crop yield. On this basis, this study was developed to identify the cation ratios (K:Mg:Ca) of the soil that best correlate with attributes indicative of 'Gália' melon production. Two experiments were carried out in two consecutive years (2017 and 2018), in a randomized-block design with five treatments and five replicates. Treatments consisted of the following cation ratios (K:Mg:Ca) for experiment I, whose soil had a $\mathrm{K}$ content of $0.40 \mathrm{cmol}_{\mathrm{c}} \mathrm{dm}^{-3}:$ T1 (1:3:34), T2 (1:3:21), T3 (1:3:9), T4 (1:0.8:9) and T5 (1:11:34); and experiment II, where the soil had $0.56 \mathrm{cmol}_{\mathrm{c}} \mathrm{dm}^{-3}$ of $\mathrm{K}: \mathrm{T} 1$ (1:1.6:29.8), T2 (1:1.4:13.3), T3 (1:1.4:8.5), T4 (1:0.5:8.5) and T5 (1:4.8:29.8). The following traits were evaluated: chemical analyses of the soil during the flowering phase and at the end of the cycle, nutrient concentration in the diagnostic leaf during the fruiting phase, total yield, marketable yield, average total weight, average marketable weight, total number of fruits and number of marketable fruits per plant. The cation ratios influenced the average total and marketable fruit weights only in experiment I, but not yield. Therefore, when associated with irrigation water from the Açu sandstone aquifer and fertigation, the high absolute $\mathrm{K}$ and medium to high $\mathrm{Mg}$ contents

${ }^{1} \mathrm{Dr}^{\mathrm{a}}$ in Agronomy, Universidade Federal Rural do Semi-Árido, UFERSA, Mossoró, RN, Brazil. E-mail: cristiane_uzl@ hotmail.com

2 Prof. Dr., Center of Agrarian Sciences, UFERSA, Campus Mossoró, RN, Brazil. E-mail: jfmedeir@ufersa.edu.br

${ }^{3}$ Dr. in Chemistry, Technical of Laboratory, UFERSA, Mossoró, RN, Brazil. E-mail: guga@ufersa.edu.br

${ }^{4}$ Prof $^{\mathrm{a}} \mathrm{Dr}^{\mathrm{a}}$, Department of Engineering and Environmental Sciences, UFERSA, Mossoró, RN, Brazil. E-mail: aroucha@ ufersa.edu.br

* Author for correspondence

Received: July 29, 2020 - Approved: Ago. 03, 2021 
are sufficient to meet the $\mathrm{K}$ and $\mathrm{Mg}$ nutrient requirements, dispensing with correction of the cation ratio.

Key words: Cucumis melo L. Potassium. Magnesium. Calcium.

\section{Resumo}

O Nordeste brasileiro destaca-se na produção e exportação de melão. Parte dos solos desta região onde se concentram os plantios da cultura é de origem calcária, assim como a água de irrigação utilizada. Estas condições, ao longo de cultivos sucessivos, podem causar a alcalinização do solo devido ao acúmulo de cátions de caráter básico do complexo de troca, como $\mathrm{Ca}, \mathrm{Mg}, \mathrm{K} \mathrm{e} \mathrm{Na}$, em solos que já são ricos em bases, influenciando a disponibilidade de nutrientes e, consequentemente, a produtividade das culturas. Baseado no exposto, o trabalho teve por objetivo identificar as relações catiônicas (K:Mg:Ca) do solo que melhor correlacionam com atributos indicadores de produção de melão Gália. Para isto, foram realizados dois experimentos, em dois anos consecutivos (2017 e 2018), em delineamento em blocos ao acaso, com cinco tratamentos e cinco repetições, consistindo das seguintes relações catiônicas (K:Mg:Ca) para o experimento I, cujo solo apresentava $0,40 \mathrm{cmol}_{\mathrm{c}} \mathrm{dm}^{-3}$ de K: T1 (1:3:34); T2 (1:3:21); T3 (1:3:9); T4 (1:0,8:9) e T5 (1:11:34) e experimento II, em que o solo tinha $0,56 \mathrm{cmol}_{\mathrm{c}} \mathrm{dm}^{-3}$ de K: T1 (1:1,6:29,8); T2 (1:1,4:13,3); T3 (1:1,4:8,5); T4 (1:0,5:8,5); T5 (1:4,8:29,8). Foram avaliadas as seguintes características: análises químicas do solo durante a fase de floração e final do ciclo, concentração de nutrientes na folha diagnóstica na fase de frutificação, produção total, produção comercial, massa média total, massa média comercial, número de frutos total e número de frutos comercial por planta. As relações catiônicas influenciaram a massa média total e comercial dos frutos apenas no experimento I, mas não o rendimento, indicando que os teores absolutos altos de $\mathrm{K}$ e médio a alto de $\mathrm{Mg}$, quando combinada com a água de irrigação do aquífero arenito Açu, associada à fertirrigação, já são suficientes para suprir a necessidade dos nutrientes $\mathrm{K}$ e Mg, dispensando, assim, correção da relação catiônica.

Palavras-chave: Cucumis melo L. Potássio. Magnésio. Cálcio.

\section{Introduction}

The northeast region of Brazil is characterized as a large producer and exporter of melon. Of the 540,229 $\mathrm{t} \mathrm{ha}^{-1}$ produced in the country, 514,276 originated in this region more specifically in the states of Rio Grande do Norte and Ceará, according to the Instituto Brasileiro de Geografia e Estatística [IBGE] (2017). Although this is considered a significant volume, some pre-harvest factors still impair nutrient uptake and, consequently, crop yield. In recent years, melon (Cucumis melo L.) cultivars deemed "noble", such as Gália, have had their planted area expanded, mainly to serve the export market.
Different soil types are found in this region, especially in terms of texture and natural fertility, with Cambisols being some of the predominant classes in most cultivated areas. Cambisols have high natural fertility but are poor in organic matter and have low levels of phosphorus available to plants (Crisóstomo etal., 2002). Due to their calcareous origin, their $\mathrm{pH}$ is neutral to alkaline, and if inadequately managed, they may compromise nutrient availability to crops as well as influence their development and productivity as a result of nutritional problems.

In addition to their limestone origin, a very important factor that contributes to 
increasing the $\mathrm{pH}$ of these soils is the practice of irrigated agriculture. It is common for the $\mathrm{pH}$ to vary across crop cycles depending on the alkalinity of the irrigation water applied, which is usually associated with the concentration of carbonates and bicarbonates in it (Dias Medeiros, Ghey, Silva, \& Barroso, 2004; Paiva et al., 2004). The main source of water used for irrigation in Chapada do Apodi is underground, originating from the Açu sandstone and Jandaíra limestone aquifers. According to Oliveira (2016), aquifers in this region have high $\mathrm{Ca}^{2+}, \mathrm{HCO}_{3}{ }^{-}$and $\mathrm{pH}$ values, so the water used to meet the water requirements of the crop possibly influences the cation ratio of the soil.

Knowing and defining the relative concentration of cations (calcium, magnesium and potassium) for these soils, which have high $\mathrm{Ca}$ levels, is very important for good plant nutrition, since they compete for the same root absorption sites, with the cation at highest concentration in the soil solution having preferential absorption over the others (Malavolta, Vitti, \& Oliveira, 1997). Moreover, high levels of monovalent cations in the soil solution can induce a deficiency of divalent cations, which are more strongly retained by the soil exchange complex (Brady \& Weil, 2013).

According to Crisóstomo et al. (2002), in melon crops grown in limestone soils of Rio Grande do Norte and Ceará, irrigated with water rich in $\mathrm{Ca}$ and fertilized with high $\mathrm{K}_{2} \mathrm{O}$ rates, potassium deficiency can still occur due to the competitive inhibition of $\mathrm{K}$ uptake by the high $\mathrm{Ca}$ contents in the soil. Moreover, high $\mathrm{Ca}$ and $\mathrm{K}$ concentrations can inhibit $\mathrm{Mg}$ uptake, reducing its translocation from root to shoot and thus causing its deficiency.
Research on the most appropriate fertilization strategy and $\mathrm{Ca}, \mathrm{K}$ and $\mathrm{Mg}$ ratios for melon growing in the conditions of the Assú valley, in a Cambisol, revealed a smaller number of defective fruits and greater exporttype production when corrective fertilizer $\mathrm{K}$ and Mg was applied (Silva, 2000).

Given the need to improve techniques to optimize nutrient application for maximizing fruit productivity while ensuring products of high commercial value, this study was undertaken to examine the performance of 'Gália' melon grown under different cation ratios in high-calcium soils.

\section{Material and Methods}

Two experiments were carried out from August to October 2107 (experiment I) and August to October 2018 (experiment II) in the municipality of Upanema - RN, Brazil. The area is situated in the Mossoró-Açu agricultural zone, at coordinates $5^{\circ} 35^{\prime} \mathrm{S}$ and $37^{\circ} 12^{\prime} \mathrm{W}$. The predominant climate in the region is hot and dry (BSwh' type, according to the Köppen classification), with very irregular rainfall, annual precipitation of $673.9 \mathrm{~mm}$, temperature of $27{ }^{\circ} \mathrm{C}$ and average relative humidity of $68.9 \%$ (Carmo \& Oliveira, 1995). During the experiments, the average daily temperature was around $28^{\circ} \mathrm{C}$ and the average daily relative humidity was $60 \%$, with no rainfall.

The experiments were conducted in different areas, in soils of the Haplic Cambisol class (Santos et al., 2018) formed on the Jandaíra limestone aquifer. Initial chemical characteristics of the soils were determined before planting, in the topsoil (0-20 cm depth). Soil analysis revealed the following properties: $\mathrm{pH}$ value $=7.5, \mathrm{~K}=0.40, \mathrm{Na}=0.14, \mathrm{Ca}=13.54$ 
and $\mathrm{Mg}=1.19 \mathrm{cmol}_{\mathrm{c}} \mathrm{dm}^{-3}$ (experiment I); and $\mathrm{pH}=8.50, \mathrm{~K}=0.56, \mathrm{Na}=0.07, \mathrm{Ca}=16.7$ and $\mathrm{Mg}=0.90 \mathrm{cmol}_{\mathrm{c}} \mathrm{dm}^{-3}$ (experiment II). The characteristics of the water used in irrigation were also determined and results were as follows: electrical conductivity (EC): $0.55 \mathrm{dS}$ $\mathrm{m}^{-1}, \mathrm{pH}: 7.8, \mathrm{~K}^{+}$: 0.44, $\mathrm{Ca}^{2+}: 2.25, \mathrm{Mg}^{2+}$ : 0.89, $\mathrm{Na}^{+}$: 2.16, $\mathrm{Cl}^{-1}: 1.31, \mathrm{HCO}_{3}^{-}: 4.0 \mathrm{mmol}_{\mathrm{C}} \mathrm{L}^{-1}$ (experiment I); and EC: $1.35 \mathrm{dS} \mathrm{m}^{-1}, \mathrm{pH}: 6.5, \mathrm{~K}^{+}: 0.15, \mathrm{Ca}^{2+}: 8.5$, $\mathrm{Mg}^{2+}: 1.5, \mathrm{Na}^{+}: 3.5, \mathrm{Cl}^{-}: 5.5$ and $\mathrm{HCO}_{3}^{-}: 7.5 \mathrm{mmol}_{\mathrm{c}}$ $\mathrm{L}^{-1}$ (experiment II).

Both experiments were carried out in a randomized-block design with five treatments and five replicates. The experimental plots consisted of two 8-m rows of plants, with the yield evaluated in $6 \mathrm{~m}$ of one of the rows. Treatments were represented by the following cation ratios (K:Mg:Ca) for experiment I: T1 - initial soil condition (1:3:34), T2 (1:3:21), T3 (1:3:9), T4 (1:0.8:9) and T5 (1:11:34); and experiment II: T1 - initial soil condition (1:1.6:29.8), T2 (1:1.4:13.3), T3 (1:1.4:8.5), T4 $(1: 0.5: 8.5)$ and T5 (1:4.8:29.8). These ratios were achieved with the application of $\mathrm{K}$ and $\mathrm{Mg}$ sources in the planting row, considering a volume of $300 \mathrm{~m}^{3}$ ha-1 $^{-1}$ of soil $(5000 \mathrm{~m} \times 0.3$ $\mathrm{m} \times 0.2 \mathrm{~m}$ ). Applications totaled 25 and 30; 50 and 60; 50 and 0; and 0 and $60 \mathrm{~kg} \mathrm{ha}^{-1}$ of $\mathrm{K}_{2} \mathrm{O}$ and $\mathrm{MgO}$ (experiment $\mathrm{I}$ ) and 20 and 40; 40 and 80; 40 and 0; and 0 and $80 \mathrm{~kg} \mathrm{ha}^{-1}$ of $\mathrm{K}_{2} \mathrm{O}$ and $\mathrm{MgO}$ (experiment II) for treatments T2, T3, T4, T5, respectively. Potassium chloride and magnesium sulfate were used as $\mathrm{K}$ and $\mathrm{Mg}$ sources, respectively, both applied at planting. In fertigation, $80 \%$ urea was used as the nitrogen source and $20 \%$ ammonium sulfate and monoammonium phosphate (MAP) as the phosphorus source.

Melon (Cucumis melo L.) hybrid Mc Laren, of the Gália variety, was used because it is currently the cultivar of this melon type with the greatest growth tendency among local producers and in order to complement studies already developed in the region.

To assess soil fertility throughout the experiments, samples were collected 30 days after sowing (DAS), when fruiting began, and at the end of the cycle (63 days), at the depth of 0 to $20 \mathrm{~cm}$, to determine the soil $\mathrm{K}, \mathrm{Ca}, \mathrm{Mg}$ and $\mathrm{Na}$ contents, in addition to $\mathrm{EC}$ and $\mathrm{pH}$.

Three soil samples were collected at a depth of $0-20 \mathrm{~cm}$ in each experimental unit, totaling 25 composite samples in each collection. These were taken to the Laboratory of Irrigation and Salinity at the Federal Rural University of the Semi-Arid - UFERSA, where they were analyzed following the methodology proposed by Empresa Brasileira de Pesquisa Agropecuária [EMBRAPA] (2017).

The samples were air-dried, sieved through a 2-mm mesh and subjected to chemical analysis. For the exchangeable cations of $\mathrm{Ca}$ and $\mathrm{Mg}$, extraction was performed with a $\mathrm{KCl} 1 \mathrm{~mol} \mathrm{~L}^{-1}$ solution and determined by EDTA complexometric titration; for the exchangeable cations $\mathrm{Na}$ and $\mathrm{K}$, extraction was performed with Mehlich $1\left(\mathrm{HCl} 0.05 \mathrm{~mol} \mathrm{~L}^{-1}+\mathrm{H}_{2} \mathrm{SO}_{4} 0.0125 \mathrm{~mol} \mathrm{~L}^{-1}\right)$ and their contents were determined in the supernatant using flame photometry. Electrical conductivity in the saturation extract and the potential of hydrogen $(\mathrm{pH})$ were measured with a conductivity meter and a $\mathrm{pH}$ meter, respectively.

Plant tissue analyses were performed at the beginning of the fruiting phase in both experiments, in samples from each experimental plot. The fifth leaf of the main branch (diagnostic leaf) was analyzed, as indicated by EMBRAPA (2009). Samples of dried plant material were crushed in a mill and 
analyzed to determine the levels of nitrogen $\mathrm{N}$, $\mathrm{P}, \mathrm{K}, \mathrm{Ca}, \mathrm{Mg}, \mathrm{Fe}, \mathrm{Mn}$ and $\mathrm{Zn}$.

Analytical procedures for determining the nutrient contents in the plant followed the methodology described by EMBRAPA (2009), with sulfuric acid digestion. After the extract was digested, determinations were performed following the steam distillation methodology (Kjeldahl Method) for $\mathrm{N}$; molybdate blue spectrophotometry for $\mathrm{P}$; and flame emission photometry for K. Atomic absorption spectrophotometry was performed for the $\mathrm{Ca}$, $\mathrm{Mg}, \mathrm{Fe}, \mathrm{Mn}$ and $\mathrm{Zn}$ contents.

The harvest took place 63 DAS, when the plant's productive performance was evaluated. Total yield was calculated by weighing all the fruits in the usable area of the experimental plot, and expressed in $\mathrm{kg}$ ha $^{-1} ;$ marketable yield was determined by counting all fruits with marketing standard, and expressed in $\mathrm{kg} \mathrm{ha}^{-1}$; number of marketable fruits per plant was calculated by counting all harvested fruits with marketing standard in the plot and dividing the result by the number of plants; average marketable fruit weight was determined as the average weight of commercial fruits, expressed in kg; total number of fruits per plant was calculated as the total number of fruits produced in the plot divided by the number of plants; and average total fruit weight was measured as the average weight of all fruits harvested in the plot, expressed in $\mathrm{kg}$.

Results were subjected to analysis of variance(ANOVA) bytheFtest. Significancewas determined at up to $5 \%$ probability. The data were generated by an electronic spreadsheet (Microsoft ${ }^{\circledR}$ Excel), after having been tested for normality and homogeneity of variance using SAEG software v. 9.0. Subsequently, the treatment means were generated, LSD was determined at a $5 \%$ significance level for Tukey's test and treatments were grouped according to the calculated LSD.

\section{Results and Discussion}

Table 1 shows the average $\mathrm{pH}, \mathrm{EC}$ and $\mathrm{Na}, \mathrm{K}, \mathrm{Ca}$ and $\mathrm{Mg}$ contents in the soil, at a depth of $0-20 \mathrm{~cm}$, in experiment I, analyzed at 30 and 63 DAS. The different cation ratios via soil fertilization at planting only influenced the $\mathrm{K}$ levels at $30 \mathrm{DAS}$, besides $\mathrm{Ca}$ and $\mathrm{Mg}$ at 63 DAS. 
Table 1

Mean fertility and salinity values, at 30 and 63 DAS, of Cambisol soil cultivated with melon and subjected to K:Ca and Mg:Ca cation ratios (0-20 cm depth) - Experiment I, Mossoró - RN, Brazil, 2020

\begin{tabular}{|c|c|c|c|c|c|c|}
\hline \multicolumn{7}{|c|}{ Experiment I, 30 DAS } \\
\hline \multirow{2}{*}{ Treatment } & $\mathrm{pH}$ & EC & $\mathrm{Na}$ & $\mathrm{K}$ & $\mathrm{Ca}$ & $\mathrm{Mg}$ \\
\hline & & $\mathrm{dS} \mathrm{m}^{-1}$ & \multicolumn{2}{|c|}{--------mg dm-3------- } & \multicolumn{2}{|c|}{----cmol $\mathrm{dm}_{\mathrm{c}}^{-3----}$} \\
\hline T1 (KOMO) & $7.80 \mathrm{a}$ & $1.54 \mathrm{a}$ & $61.8 \mathrm{a}$ & $99.0 \mathrm{ab}$ & $10.8 \mathrm{a}$ & $2.64 \mathrm{a}$ \\
\hline T2 (K1M1) & $7.73 \mathrm{a}$ & $1.37 \mathrm{a}$ & $56.6 \mathrm{a}$ & $118.0 \mathrm{ab}$ & $11.9 \mathrm{a}$ & $2.29 a$ \\
\hline T3 (K2M2) & $7.73 \mathrm{a}$ & $3.60 \mathrm{a}$ & $64.6 \mathrm{a}$ & $164.0 \mathrm{a}$ & $11.6 \mathrm{a}$ & $2.01 \mathrm{a}$ \\
\hline $\mathrm{T} 4$ (K2M0) & $7.80 \mathrm{a}$ & $2.01 \mathrm{a}$ & $61.2 \mathrm{a}$ & $198.0 \mathrm{a}$ & $10.8 \mathrm{a}$ & $2.79 a$ \\
\hline T5 (KOM2) & $7.71 \mathrm{a}$ & $3.15 a$ & $58.8 \mathrm{a}$ & $93.0 \mathrm{~b}$ & $12.0 \mathrm{a}$ & $2.77 \mathrm{a}$ \\
\hline CV (\%) & 1.0 & 54.4 & 17.9 & 19.5 & 9.7 & 16.6 \\
\hline \multicolumn{7}{|c|}{ Experiment I, 63 DAS } \\
\hline T1 (KOMO) & $7.92 \mathrm{a}$ & $1.43 \mathrm{a}$ & $81.8 \mathrm{a}$ & $101.1 \mathrm{ab}$ & $8.2 \mathrm{~b}$ & $2.0 \mathrm{a}$ \\
\hline T2 (K1M1) & $7.86 \mathrm{a}$ & $1.59 \mathrm{a}$ & $85.2 \mathrm{a}$ & $106.0 \mathrm{ab}$ & $8.9 a b$ & $1.78 \mathrm{a}$ \\
\hline T3 (K2M2) & $7.88 \mathrm{a}$ & $1.85 \mathrm{a}$ & $79.2 \mathrm{a}$ & $118.0 \mathrm{ab}$ & $8.5 b$ & $1.83 \mathrm{a}$ \\
\hline T4 (K2MO) & $7.89 a$ & $1.36 \mathrm{a}$ & $71.0 \mathrm{a}$ & $150.0 \mathrm{a}$ & $9.4 \mathrm{ab}$ & $1.31 \mathrm{ab}$ \\
\hline T5 (KOM2) & $7.89 a$ & $1.38 a$ & $66.8 \mathrm{a}$ & $91.0 \mathrm{~b}$ & $10.2 \mathrm{a}$ & $0.79 \mathrm{~b}$ \\
\hline CV (\%) & 1.2 & 48.5 & 25.6 & 25.5 & 8.6 & 26.8 \\
\hline
\end{tabular}

$\mathrm{pH}$ - potential of hydrogen; EC - electrical conductivity; $\mathrm{Na}$ - sodium; K - potassium; Ca - calcium; Mg - magnesium. Different letters in the columns indicate significant differences between treatments at $5 \%$ by Tukey's test.

At 30 DAS, there was no significant effect between treatments for $\mathrm{pH}$ (Table 1). The $\mathrm{pH}$ results revealed little variation between the minimum and maximum values obtained in treatments KOM2 (7.71) and KOMO and K2MO (7.80), respectively. These results are due to the initial alkalinity of the soil, which, before the implementation of the experiment, had a pH of 7.5; and the irrigation water used, which has high levels of bases and $\mathrm{HCO}_{3}$. Several factors can affect crop development, e.g., soil $\mathrm{pH}$, which plays a critical role in nutrient availability to plants (Stevens, Dunn, \& Phipps, 2001; Shen et al., 2011). At 63 DAS, the treatments also did not influence the $\mathrm{pH}$ in the analyzed $0-20 \mathrm{~cm}$ layer (Table 1), which showed a small variation between the treatments, from 7.86 (K1M1) to 7.92 (KOMO). This response is due to the initial soil condition (slightly alkaline). When the soil $\mathrm{pH}$ is outside the ideal range (low), it can cause aluminum and manganese toxicity in plants, reducing the availability of phosphorus in the soil. When too high, the availability of micronutrients such as zinc and boron, as well as phosphorus, can be reduced (Stevens et al., 2001).

Electrical conductivity in the soil at 30 DAS ranged from 1.37 to $3.60 \mathrm{dS} \mathrm{m}^{-1}$. Even so, there was no difference between the treatments (Table 1), given the high coefficient of variation (CV). This was possibly due to the localized application of the fertilizers, which substantially increases sampling errors, considering that sampling was performed using a 1.5" Dutch auger (hole diameter of $4 \mathrm{~cm}$ ) at three points in each plot. However, the maximum EC was obtained in treatment $\mathrm{K} 2 \mathrm{M} 2$, which is characterized as the treatment 
that received the highest amount of $\mathrm{K}$ and $\mathrm{Mg}$ (potassium chloride and magnesium sulfate). According to Anjos, Hernandez, Costa Caballero and Moreira (2015), EC increases as a result of increasing amounts of $\mathrm{KCl}$, which highlights the saline effect of the fertilizer. This may explain the higher EC values in treatment T3 (K2M2), which received the highest concentration of K. Melo et al. (2011) observed that the marketable and total yields of 'Gália' melon were not affected by water salinity up to the levels of 1.48 and 1.46 dS $\mathrm{m}^{-1}$, respectively. At 63 days, there was also no significant difference between the treatments (Table 1), with EC ranging from 1.38 (KOM2) to 1.85 (K2M2) dS m-1. According to Ayers and Westcot (1999), melon tolerates $\mathrm{EC} \leq 2.2$ dS $\mathrm{m}^{-1}$ without loss of crop development.

Sodium contents in the soil at 30 days did not change between treatments (Table 1). Treatment T2 (K1M1) provided the lowest Na value (56.6 $\mathrm{mg} \mathrm{dm}^{-3}$ ), and treatment T3 (K2M2) the highest $\left(64.6 \mathrm{mg} \mathrm{dm}^{-3}\right)$. At 63 days, there were no significant differences, either. The $\mathrm{Na}$ values ranged from 66.8 (KOM2) to 85.2 (K1M1) $\mathrm{mg} \mathrm{dm}^{-3}$. The lowest $\mathrm{Na}$ content was found in the treatment in which $\mathrm{K}$ was not added, combined with the highest $\mathrm{Mg}$ rate, whereas the highest value was obtained when the intermediate rate of both $\mathrm{K}$ and $\mathrm{Mg}$ was used. According to Moraes (2009), in regions where base saturation is high, the presence of salts such as bicarbonates and carbonates of $\mathrm{Ca}, \mathrm{Mg}$ and $\mathrm{Na}$ establishes the predominance of hydroxyl ions $\left(\mathrm{OH}^{-}\right)$over hydrogen ions $\left(\mathrm{H}^{+}\right)$ in the soil solution, giving alkalinity to these soils.

Potassium in the soil differed significantly between the treatments at 30 days (Table 1). This result is associated with its application to the soil, where treatment T4
(K2M0), which consisted of the highest applied $\mathrm{K}$ rate without $\mathrm{Mg}$, had a higher concentration of the element in the soil $\left(198.0 \mathrm{mg} \mathrm{dm}^{-3}\right)$. Treatment 4 differed only from treatment T5, where no K was applied, but more Mg (KOM2). Because this element is bivalent and no $\mathrm{K}$ was applied, the $\mathrm{Mg}$ may have displaced the $\mathrm{K}$ into the solution and been leached or absorbed by the plant. The absolute $\mathrm{K}$ values for treatments T3 and T4, which received the highest rate applied to the soil, are classified as very high (> $120 \mathrm{mg} \mathrm{dm}^{-3}$ ) according to Holanda et al. (2017). At 63 days, statistical differences were also present between the adopted treatments. The $\mathrm{K}$ content ranged from 91.0 (KOM2) to 150.0 (K2M0) mg dm${ }^{-3}$ (Table 1) between treatments. The highest $\mathrm{K}$ levels in the soil were observed in the treatment that received the highest amount of potassium chloride, corresponding to a K:Mg:Ca ratio of 1:0.8:9 in the soil.

Calcium contents in the soil showed no significant differences between the treatments at 30 days (Table 1). Across the treatments, this variable ranged from 10.8 (KOMO and K2MO) to 12.0 (KOM2) cmolc $\mathrm{dm}^{-3}$. High $\mathrm{K}$ rates can displace $\mathrm{Ca}$, thus reducing the cation ratio in the soil and favoring the availability of nutrients for the plant. The $\mathrm{Ca}$ values considered absolute in this study

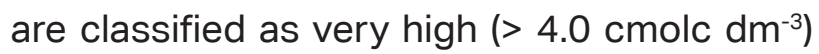
according to Holanda et al. (2017). At 63 days, the $\mathrm{Ca}$ levels differed significantly between treatments, varying from 8.56 (KOMO) to 10.2 (KOM2) $\mathrm{cmol}_{\mathrm{c}} \mathrm{dm}^{-3}$ (Table 1). Jakobsen (1993) stated that the application of potassium chloride causes a momentary increase in the uptake of different cations, such as $\mathrm{Ca}$ and Mg. However, after chloride leaching, the high residual $\mathrm{K}$ contents can induce a decrease in $\mathrm{Ca}$ and $\mathrm{Mg}$ activities in solution, reducing their uptake by plants. 
Magnesium in the soil at 30 days did not differ between treatments, ranging from 2.01 (K2M2) to $2.77(\mathrm{KOM} 2) \mathrm{cmol}_{\mathrm{c}} \mathrm{dm}^{-3}$ (Table 1). The highest value of the element in the soil was achieved with the treatment involving the highest $\mathrm{Mg}$ rate and no $\mathrm{K}$. This smaller range may be due to the masking caused by $\mathrm{Mg}$ from the irrigation water, which represents a significant amount when compared with that added to the soil. The high $\mathrm{CV}$ also contributes to a non-significant difference between the means. According to Holanda et al. (2017), these $\mathrm{Mg}$ contents are classified as very $\operatorname{good}\left(>1.5 \mathrm{cmol}_{\mathrm{c}} \mathrm{dm}^{-3}\right)$. At 63 days, there was a significant difference between treatments
(Table 1), with the $\mathrm{Mg}$ content ranging from 0.79 (KOM2) to $2.0(\mathrm{KOMO}) \mathrm{cmol}_{\mathrm{c}} \mathrm{dm}^{-3}$. The fact that this difference was identified only at the end of the cycle may be related to the accumulation of this nutrient in the soil originating from irrigation water, which had high concentrations of this element.

Table 2 shows the mean $\mathrm{pH}, \mathrm{EC}, \mathrm{Na}$, $\mathrm{K}, \mathrm{Ca}$ and $\mathrm{Mg}$ in the soil at a depth of $0-20 \mathrm{~cm}$ analyzed at 30 and 63 DAS in experiment II. The different cation ratios via soil fertilization at planting influenced only the levels of $\mathrm{Na}$, $\mathrm{Ca}$ and $\mathrm{Mg}$ at 30 days, whereas at 63 days no parameter was influenced.

\section{Table 2}

Mean fertility and salinity values, at 30 and 63 DAS, of Cambisol soil cultivated with melon and subjected to $\mathrm{K}: \mathrm{Ca}$ and Mg:Ca cation ratios (0-20 cm depth) - Experiment II, Mossoró - RN, Brazil, 2020

\begin{tabular}{ccccccc} 
& \multicolumn{7}{c}{ Experiment II, 30 DAS } \\
Treatment & $\mathrm{pH}$ & $\mathrm{EC}$ & $\mathrm{Na}$ & $\mathrm{K}$ & $\mathrm{Ca}$ & $\mathrm{Mg}$ \\
\cline { 2 - 7 } T1 (KOM0) & $7.53 \mathrm{a}$ & $1.24 \mathrm{a}$ & $76.6 \mathrm{a}$ & $366.2 \mathrm{a}$ & $14.3 \mathrm{a}$ & $2.54 \mathrm{~b}$ \\
\hline T2 (K1M1) & $7.64 \mathrm{a}$ & $1.27 \mathrm{a}$ & $73.0 \mathrm{ab}$ & $342.9 \mathrm{a}$ & $13.9 \mathrm{ab}$ & $3.45 \mathrm{ab}$ \\
\hline T3 (K2M2) & $7.32 \mathrm{a}$ & $1.20 \mathrm{a}$ & $77.7 \mathrm{a}$ & $420.4 \mathrm{a}$ & $11.5 \mathrm{~b}$ & $3.71 \mathrm{ab}$ \\
\hline T4 (K2M0) & $7.47 \mathrm{a}$ & $1.14 \mathrm{a}$ & $65.7 \mathrm{ab}$ & $360.5 \mathrm{a}$ & $12.0 \mathrm{ab}$ & $4.57 \mathrm{a}$ \\
\hline T5 (KOM2) & $7.32 \mathrm{a}$ & $1.35 \mathrm{a}$ & $55.5 \mathrm{~b}$ & $321.1 \mathrm{a}$ & $11.9 \mathrm{ab}$ & $4.31 \mathrm{a}$ \\
CV (\%) & 2.8 & 18.2 & 15.0 & 14.3 & 10.0 & 15.8 \\
& & \multicolumn{7}{c}{ Experiment II, 63 DAS } & & \\
T1 (KOM0) & $7.62 \mathrm{a}$ & $2.42 \mathrm{a}$ & $101.1 \mathrm{a}$ & $191.9 \mathrm{a}$ & $13.7 \mathrm{a}$ & $6.45 \mathrm{a}$ \\
T2 (K1M1) & $7.66 \mathrm{a}$ & $2.48 \mathrm{a}$ & $125.5 \mathrm{a}$ & $240.9 \mathrm{a}$ & $13.5 \mathrm{a}$ & $6.13 \mathrm{a}$ \\
T3 (K2M2) & $7.65 \mathrm{a}$ & $1.95 \mathrm{a}$ & $104.2 \mathrm{a}$ & $217.7 \mathrm{a}$ & $13.1 \mathrm{a}$ & $6.25 \mathrm{a}$ \\
T4 (K2M0) & $7.68 \mathrm{a}$ & $2.08 \mathrm{a}$ & $97.9 \mathrm{a}$ & $222.3 \mathrm{a}$ & $12.8 \mathrm{a}$ & $6.08 \mathrm{a}$ \\
T5 (KOM2) & $7.28 \mathrm{a}$ & $1.77 \mathrm{a}$ & $107.5 \mathrm{a}$ & $198.7 \mathrm{a}$ & $12.7 \mathrm{a}$ & $6.46 \mathrm{a}$ \\
CV (\%) & 3.8 & 28.5 & 22.8 & 24.2 & 7.1 & 17.1
\end{tabular}

$\mathrm{pH}$ - potential of hydrogen; $\mathrm{EC}_{\mathrm{se}}$ - electrical conductivity; $\mathrm{Na}$ - sodium; $\mathrm{K}$ - potassium; $\mathrm{Ca}$ - calcium; Mg - magnesium. Different letters in the columns indicate significant differences between treatments at $5 \%$ by Tukey's test.

At 30 days, the applied treatments did not affect the soil $\mathrm{pH}$ (Table 2), which exhibited a small variation from 7.32 (K2M2 and $\mathrm{KOM} 2$ ) to 7.64 (K1M1). At $63 \mathrm{DAS}$, the $\mathrm{pH}$ 
values also did not differ between treatments (Table 2) and ranged from 7.28 (KOM2) to 7.68 (K2M0). Overall, higher values were observed at 63 days relative to 30 days, due to the accumulation of basic cations of the exchange complex, such as $\mathrm{Ca}, \mathrm{Mg}, \mathrm{K}$ and $\mathrm{Na}$, throughout the cycle, which contributed for the $\mathrm{pH}$ of these soils to increase (Moraes, 2009). This is because the volume of water for irrigation from 30 days onwards was much larger, as $80 \mathrm{~mm}$ were used until 30 days and after that period, up to 63 days, the volume applied was $231 \mathrm{~mm}$, with a higher concentration of bases in comparison to the former.

Electrical conductivity in the 0-20 $\mathrm{cm}$ layer at 30 DAS did not differ between treatments (Table 2), ranging from 1.14 (K2M0) to 1.35 (KOM2) $\mathrm{dS} \mathrm{m}^{-1}$. Overall, EC in experiment I was greater than in experiment II, and this may be directly related to the higher initial EC of the soil in experiment I. At 63 days, there was also no significant difference between treatments, as observed in Table 2. Electrical conductivity was higher at 63 days than at 30 days, which may be mainly due to the EC of the irrigation water (1.35 dS $\left.\mathrm{m}^{-1}\right)$ that was applied at around $80 \%$ between 30 and 63 days.

Sodium values in the soil showed significant differences at 30 DAS (Table 2), with treatment $\mathrm{T} 3(\mathrm{~K} 2 \mathrm{M} 2)$ providing the highest mean $\left(77.7 \mathrm{mg} \mathrm{dm}^{-3}\right)$. This treatment had the highest $\mathrm{K}$ and $\mathrm{Mg}$ rates applied to the soil, which may have contributed to this result. However, this treatment did not differ from the others, except for T5 (KOM2), which provided an average $\mathrm{Na}$ content of $55.0 \mathrm{mg} \mathrm{dm}^{-3}$. At 63 days, the Na values did not differ significantly between treatments (Table 2), ranging from 97.9 (K2M0) to 125.5 (K1M1) $\mathrm{mg} \mathrm{dm}^{-3}$. The lowest value $\left(97.9 \mathrm{mg} \mathrm{dm}^{-3}\right.$ ) was obtained in the treatment that showed the lowest $\mathrm{K}: \mathrm{Mg}: \mathrm{Ca}$ cation ratio (1:0.5:8.5), that is, where more $\mathrm{K}$ and $\mathrm{Mg}$ was applied at corrective fertilizer application.

Potassium in the soil at 30 days did not differ significantly between treatments (Table 2), ranging from 321.1 (KOM2) to 420.4 (K2M2) $\mathrm{mg} \mathrm{dm}^{-3}$. The latter treatment consisted of the cation ratio with the highest levels of $K$ and $\mathrm{Mg}$ applied to the soil, which may have contributed to the higher value. Potassium values in experiment II were much higher than in experiment I, which may be related to the higher concentration of this element in the soil before the implementation of the experiment. The absolute $\mathrm{K}$ values in the soil are classified as very good (> $120 \mathrm{mg} \mathrm{dm}^{-3}$ ), according to Holanda et al. (2017). At 63 days, there was also no difference between treatments (Tables 2). Potassium values ranged from 191.9 (KOMO) to 240.9 (K1M1) mg dm ${ }^{-3}$. Overall, the $K$ values showed a decline as compared with those achieved at 30 days. This can be explained by the uptake of these nutrients throughout the plant's development and consequent redistribution to the preferential drains (fruits), in addition to the leaching of the element in the soil profile due to irrigation. The lack of differences between treatments can be explained by the high concentration of $\mathrm{K}$ in the soil, with the $\mathrm{K}$ applied in the corrective fertilizer application representing a smaller fraction of the content present in the soil.

Calcium showed significant differences between treatments at 30 days (Table 2), when treatment T1 (KOMO) (initial soil condition) differed from treatment T3 (K2M2). This is explained by the fact that the initial soil condition included a K:Mg:Ca ratio of 1:1.6:29.8, which is considered a high $\mathrm{Ca}$ value. In treatment $\mathrm{T3}$, the $\mathrm{K}: \mathrm{Mg}: \mathrm{Ca}$ ratio was corrected to 1:1.4:8.5, containing a lower 
relative $\mathrm{Ca}$ concentration in the soil, which explains the significant difference. The higher $\mathrm{K}$ and $\mathrm{Mg}$ rates applied can displace the adsorbed $\mathrm{Ca}$ into the soil solution, and causing it to leach and reducing its concentration in the soil. In absolute terms in the soil, these values (11.5 to $14.3 \mathrm{cmol}_{\mathrm{c}} \mathrm{dm}^{-3}$ ) are classified as very good (> $4.0 \mathrm{cmol}_{\mathrm{c}} \mathrm{dm}^{-3}$ ) according to Holanda et al. (2017). At 63 days, however, there was no significant difference between treatments (Table 2). There was a variation between treatments KOM2 $\left(12.7 \mathrm{cmol}_{\mathrm{c}} \mathrm{dm}^{-3}\right)$ and KOMO $\left(13.7 \mathrm{cmol}_{\mathrm{c}} \mathrm{dm}^{-3}\right)$. These high values which are very high when compared with what the plant absorbs are due to the high levels of $\mathrm{Ca}$ in the soil, in addition to that from irrigation water.

Magnesium in the soil at 30 days showed a significant difference between treatments (Table 2), ranging from 2.54 (MOKO) to $4.57(\mathrm{~K} 2 \mathrm{MO}) \mathrm{cmol}_{\mathrm{c}} \mathrm{dm}^{-3}$. According to Holanda et al. (2017), these Mg contents are classified as very good $\left(>1.5 \mathrm{cmol}_{\mathrm{c}} \mathrm{dm}^{-3}\right)$. At 63 days, there was no significant difference between treatments for this variable (Table 2). Magnesium values ranged from 6.08 (K2M0) to $6.46(\mathrm{KOM} 2) \mathrm{cmol}_{\mathrm{c}} \mathrm{dm}^{-3}$. The highest $\mathrm{Mg}$ concentration in the soil occurred in the treatment in which the highest amount of this nutrient was applied to the soil, in combination with the absence of $\mathrm{K}$ (KOM2), with a $\mathrm{K}: \mathrm{Mg}: \mathrm{Ca}$ ratio of 1:4.8:29.8, whereas the lowest value was obtained without application of $\mathrm{Mg}$ in combination with the highest $\mathrm{K}$ rate (K2M0), with a cation ratio of $1: 0.5: 8.5$. This would be the expected result, since the lack of $\mathrm{Mg}$ application associated with the application of more Kallows the displacement of Mg to the soil solution, which can be more easily absorbed or leached into the soil profile. However, Mg from irrigation water can mask the greater difference between treatments. When we compare the concentrations of this nutrient at 30 and 63 days, a higher concentration is observed at 63 days, which is related to the accumulation caused by irrigation water.

The mean contents of $\mathrm{N}, \mathrm{P}, \mathrm{K}, \mathrm{Ca}, \mathrm{Mg}$, $\mathrm{Fe}, \mathrm{Mn}$ and $\mathrm{Zn}$ in the diagnostic leaf (Table 3) collected at 38 DAS, in experiment $\mathrm{l}$, show that the treatments only did not significantly affect the Fe micronutrient, according to Tukey's test at $5 \%$ probability as well as the $\mathrm{CV}$, which ranged from low to very high.

Table 3

Mean values of macro- and micronutrient concentrations in the diagnostic leaf of 'Gália' melon grown in a Cambisol and subjected to $\mathrm{K}: \mathrm{Ca}$ and Mg:Ca cation ratios, at $38 \mathrm{DAS}$ - Experiment I. Mossoró - RN, Brazil, 2020

\begin{tabular}{|c|c|c|c|c|c|c|c|c|}
\hline \multirow{2}{*}{ Treatment } & $\mathrm{N}$ & $\mathrm{P}$ & $\mathrm{K}$ & $\mathrm{Ca}$ & $\mathrm{Mg}$ & $\mathrm{Fe}$ & $\mathrm{Mn}$ & $\mathrm{Zn}$ \\
\hline & \multicolumn{5}{|c|}{----------------'g kg } & \multicolumn{3}{|c|}{----------mg kg-1---------- } \\
\hline T1 (KOM0) & $40.0 \mathrm{a}$ & $18.2 \mathrm{a}$ & $43.3 \mathrm{a}$ & $45.0 \mathrm{a}$ & $5.60 a b$ & $29.4 \mathrm{a}$ & $8.38 a b$ & $18.7 a b$ \\
\hline T2 (K1M1) & 37.7 a & $17.6 \mathrm{a}$ & $27.4 a b$ & 33.7ab & $4.10 \mathrm{~b}$ & 38.7 a & $9.10 \mathrm{a}$ & $15.8 \mathrm{ab}$ \\
\hline T3 (K2M2) & $32.1 \mathrm{~b}$ & $13.1 \mathrm{ab}$ & $18.1 \mathrm{~b}$ & $22.6 \mathrm{~b}$ & $2.38 \mathrm{~b}$ & 27.9 a & 7.98ab & $9.8 b$ \\
\hline T4 (K2M0) & 33.0ab & $14.2 \mathrm{ab}$ & $39.3 a b$ & $27.0 \mathrm{ab}$ & $2.71 \mathrm{~b}$ & $26.1 \mathrm{a}$ & $7.40 \mathrm{~b}$ & $18.2 a b$ \\
\hline T5 (KOM2) & 34.3ab & $11.3 b$ & $44.4 \mathrm{a}$ & $43.4 \mathrm{a}$ & $8.30 a$ & $36.6 \mathrm{a}$ & 8.70ab & $24.7 \mathrm{a}$ \\
\hline CV (\%) & 5.6 & 20.4 & 35.2 & 27.5 & 27.5 & 22.6 & 9.6 & 27.7 \\
\hline
\end{tabular}

$\mathrm{N}$ - nitrogen; P - phosphorus; K - potassium; Ca - calcium; Mg - magnesium; Fe - iron; Mn - manganese; Zn - zinc. Different letters in the columns indicate significant differences between treatments at $5 \%$ by Tukey's test. 
The $\mathrm{N}$ content in the melon leaves in experiment I (Table 3) differed significantly between treatments, with the highest mean detected in treatment T1 (KOMO) $\left(40.0 \mathrm{~g} \mathrm{~kg}^{-1}\right)$. This treatment differed only from T3 (K2M2), which received the highest application of $K$ and $\mathrm{Mg}$, having an average $\mathrm{N}$ content of $32.1 \mathrm{~g}$ $\mathrm{kg}^{-1}$ (Table 3). For Kämpf (2005), growth media with acidic $\mathrm{pH}$ are associated with deficiency of nutrients such as N, K, Ca and Mg in plants, whereas at alkaline $\mathrm{pH}$, a characteristic of the soil under study, there tend to be problems of availability of $\mathrm{P}$ and micronutrients such as $\mathrm{Fe}, \mathrm{Mn}, \mathrm{Zn}$ and $\mathrm{Cu}$. This explains the higher concentration of $\mathrm{N}$ in the more alkaline cation ratio. The values obtained in all treatments are within the recommended range of 25 to $50 \mathrm{~g}$ $\mathrm{kg}^{-1}$ for the melon crop according to Taniguchi, Crisóstomo and Artur (2019). In experiment II, there was no difference in $\mathrm{N}$ content between treatments (Table 4), with results ranging from 46.2 (K2M2) to 62.0 (KOM2) g kg-1. Treatments $\mathrm{T} 1, \mathrm{~T} 2$ and T5 provided values above the range for the crop according to Taniguchi et al. (2019).

The phosphorus in experiment I differed between treatments (Table 3). The cation ratio in $\mathrm{KOMO}$ provided the highest mean $\left(18.2 \mathrm{~g} \mathrm{~kg}^{-1}\right)$, differing only from the cation ratio in $\mathrm{KOM} 2$, whose average $\mathrm{P}$ content was $11.3 \mathrm{~g} \mathrm{~kg}^{-1}$. This nutrient diffuses slowly and has high fixation in the soil (Epstein \& Bloom, 2006; Shen et al., 2011), and may, therefore, not show a direct relationship between soil and plant contents. The $\mathrm{P}$ contents were all above the range considered normal for melon (Taniguchi et al., 2019). In experiment II, there was no difference between treatments (Table 4). The $P$ values, which ranged from 3.40 (K2M0) to $6.66(\mathrm{~K} 1 \mathrm{M} 1) \mathrm{g} \mathrm{kg}^{-1}$, are within the interval of 3 to $7 \mathrm{~g} \mathrm{~kg}^{-1}$ deemed adequate by Taniguchi et al. (2019). It is important to stress that the soil received corrective $P$ fertilizer, equivalent to $120 \mathrm{~kg} \mathrm{ha}^{-1}$ of $\mathrm{P}_{2} \mathrm{O}_{5}$, at planting.

\section{Table 4}

Mean values of macro- and micronutrient concentrations in the diagnostic leaf of "Gália" melon grown in a Cambisol and subjected to $\mathrm{K}: \mathrm{Ca}$ and $\mathrm{Mg}: \mathrm{Ca}$ cation ratios, at $38 \mathrm{DAS}$ - Experiment II. Mossoró - RN, Brazil, 2020

\begin{tabular}{|c|c|c|c|c|c|c|c|c|}
\hline \multirow{2}{*}{ Treatment } & $\mathrm{N}$ & $\mathrm{P}$ & $\mathrm{K}$ & $\mathrm{Ca}$ & $\mathrm{Mg}$ & $\mathrm{Fe}$ & $\mathrm{Mn}$ & $\mathrm{Zn}$ \\
\hline & \multicolumn{5}{|c|}{ 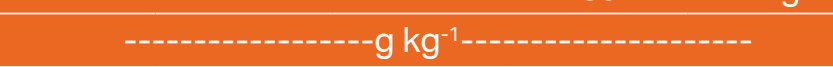 } & \multicolumn{3}{|c|}{----------mg kg'1---------- } \\
\hline T1 (KOMO) & $59.2 \mathrm{a}$ & $3.92 \mathrm{a}$ & $20.2 \mathrm{a}$ & $19.7 \mathrm{a}$ & $2.99 \mathrm{~b}$ & 149.6a & $50.6 \mathrm{a}$ & $27.4 \mathrm{a}$ \\
\hline T2 (K1M1) & $52.9 a$ & $6.66 \mathrm{a}$ & $18.0 \mathrm{a}$ & $22.6 \mathrm{a}$ & 3.09ab & 162.6a & $51.3 a$ & $22.0 \mathrm{a}$ \\
\hline T3 (K2M2) & $46.2 \mathrm{a}$ & $4.67 \mathrm{a}$ & $18.7 \mathrm{a}$ & $20.1 \mathrm{a}$ & $3.49 \mathrm{a}$ & $119.2 a$ & $46.1 \mathrm{a}$ & $26.9 a$ \\
\hline T4 (K2M0) & $47.6 \mathrm{a}$ & $3.40 \mathrm{a}$ & $20.6 a$ & $21.9 a$ & $2.88 \mathrm{~b}$ & $112.4 a$ & $52.1 \mathrm{a}$ & $21.9 a$ \\
\hline T5 (KOM2) & $62.0 \mathrm{a}$ & $4.65 a$ & $19.7 \mathrm{a}$ & $22.0 \mathrm{a}$ & $3.65 \mathrm{a}$ & $135.4 a$ & $48.2 \mathrm{a}$ & $25.3 a$ \\
\hline CV (\%) & 19.7 & 38.9 & 10 & 11.5 & 8.9 & 20.7 & 10.9 & 18.6 \\
\hline
\end{tabular}

$\mathrm{N}$ - nitrogen; P - phosphorus; K - potassium; Ca - calcium; Mg - magnesium; Fe - iron; Mn - manganese; Zn - zinc. Different letters in the columns indicate significant differences between treatments at $5 \%$ by Tukey's test. 
There was a significant difference for the potassium concentration in the diagnostic leaf in experiment I (Table 3). Treatment T5 provided the highest mean (44.4 $\left.\mathrm{g} \mathrm{kg}^{-1}\right)$, differing from treatment T3. Potassium and $\mathrm{Mg}$ absorbed by the roots and accumulated in the plant shoots can be remobilized to meet the nutritional requirements of younger tissues, when there is a decrease in their availability in the rhizosphere. The value found with treatment T3 (18.1) is below the recommended range for the crop according to Taniguchi et al. (2019). The combination of this treatment with the higher $\mathrm{Mg}$ rate may have inhibited $\mathrm{K}$ uptake; in addition, divalent cations, such as $\mathrm{Mg}$, have preferential uptake over monovalent cations (K). In experiment II, the $\mathrm{K}$ contents varied from 18.0 (K1M1) to 20.6 (K2M0) g $\mathrm{kg}^{-1}$. The lower concentrations relative to experiment I are related to the dilution effect, as the plants initially showed vigorous growth. According to Taniguchi et al. (2019), the values of all treatments are below the recommended range of 25 to $40 \mathrm{~g} \mathrm{~kg}^{-1}$ for the melon crop.

The calcium content in the leaves also varied between treatments in experiment I (Table 3), with treatment T1 (KOMO) providing the highest mean $\left(45.0 \mathrm{~g} \mathrm{~kg}^{-1}\right)$ and differing only from treatment T3 $\left(22.6 \mathrm{~g} \mathrm{~kg}^{-1}\right)$. The Ca content found in treatment T3 was slightly below $25 \mathrm{~g}$ $\mathrm{kg}^{-1}$, the lower limit suggested by Taniguchi et al. (2019). These values are directly related to the concentration of this nutrient in the soil, as treatment $\mathrm{T} 1$ refers to the $\mathrm{K}: \mathrm{Mg}: \mathrm{Ca}$ cation ratio of 1:3:34, whereas treatment 3 refers to the cation ratio of 1:3:9, which explains the greater concentration in the leaf. In experiment II (Table 4), Ca ranged from 19.7 (KOMO) to 22.6 (K1M1) $\mathrm{g} \mathrm{kg}^{-1}$, without differences between treatments. The values found in all treatments are below the recommended range of 25 to
$50 \mathrm{~g} \mathrm{~kg}^{-1}$ according to Taniguchi et al. (2019). These are directly related to the dilution effect, as the plants were very vigorous at 38 days.

There was a significant difference between treatments for magnesium in experiment I (Table 3), whose highest mean (8.30 $\mathrm{g} \mathrm{kg}^{-1}$ ) was achieved in treatment T5 (KOM2), where more Mg was applied without the application of $\mathrm{K}$ and which differed from treatments T2, T3 and T4. The highest mean refers to the $\mathrm{K}: \mathrm{Mg}: \mathrm{Ca}$ ratio of $1: 11: 34$. According to Jakobsen (1993), the application of potassium chloride causes a momentary increase in the uptake of other cations, such as $\mathrm{Ca}$ and $\mathrm{Mg}$; however, after chloride leaching, the high residual $\mathrm{K}$ contents can induce a reduction in the $\mathrm{Ca}$ and $\mathrm{Mg}$ activities in solution, reducing their uptake by plants. In experiment II, there was also a difference between treatments (Table 4). Treatment T5 (KOM2) had the highest mean (3.65 $\mathrm{g} \mathrm{kg}^{-1}$ ), differing from treatments $\mathrm{T} 1$ (KOMO) and $\mathrm{T} 4$ (K2M0), whose average $\mathrm{Mg}$ contents were 2.99 and $2.88 \mathrm{~g} \mathrm{~kg}^{-1}$, respectively. Ideal $\mathrm{Mg}$ contents, as recommended by Taniguchi et al. (2019), range from 5.0 to $12.0 \mathrm{~g} \mathrm{~kg}^{-1}$, and values below it may be related to a dilution effect, since the plants were more vigorous. The highest $\mathrm{Mg}$ value was found in treatment T5, where the largest amount of magnesium was added to the soil, which may have favored the uptake of this nutrient by the plants.

In the case of micronutrients, only iron in experiment I did not show any significant difference between treatments (Table 3), with values ranging from 26.1 (K2M0) to 38.7 (K1M1) $\mathrm{mg} \mathrm{kg}^{-1}$. These values are outside the range of 50 to $300 \mathrm{mg} \mathrm{kg}^{-1}$ considered ideal for the crop according to Taniguchi et al. (2019). The Fe contents found in experiment II varied from 112.4 (K2M0) to 162.6 (K1M1) $\mathrm{mg} \mathrm{kg}^{-1}$, but also did not differ between treatments. 
The manganese content differed significantly between treatments in experiment I (Table 3), with the highest mean provided by treatment T2 (9.10), which differed only from treatment T4 $\left(7.40 \mathrm{mg} \mathrm{kg}^{-1}\right)$. The $\mathrm{Mn}$ results are below the recommended values for melon crop according to Taniguchi et al. (2019), who mentioned that the ideal range for the crop is between 50 and $250 \mathrm{mg} \mathrm{kg}^{-1}$. Soils with alkaline $\mathrm{pH}$ tend to have problems in availability of $\mathrm{P}$ and micronutrients such as $\mathrm{Fe}$, Mn, Zn and Cu (KÄMPF, 2005). In experiment II (Table 4), Mn varied from 46.1 (K2M2) to 52.1 (K2M0) $\mathrm{mg} \mathrm{kg}^{-1}$, and the values found in treatments T3 and T5 are below the range considered ideal for the melon crop, according to Taniguchi et al. (2019).

The zinc content in the leaf in experiment I differed between treatments
(Table 3): treatment T5 (KOM2) provided the highest mean (24.7 $\left.\mathrm{mg} \mathrm{kg}^{-1}\right)$, differing from treatment T3 (K2M2), whose mean was 9.8 $\mathrm{mg} \mathrm{kg}^{-1}$. This value is outside the range of 20-100 mg kg-1 considered ideal for the crop according to Taniguchi et al. (2019), and may also be related to soil alkalinity. In experiment II, the Zn content varied from 21.9 (K2M0) to 27.4 (KOMO) $\mathrm{mg} \mathrm{kg}^{-1}$, which is within the range of $20-100 \mathrm{mg} \mathrm{kg}^{-1}$ mentioned by Taniguchi et al. (2019) as ideal for the crop.

Tables 5 and 6 show the mean values of the production variables in experiments I and II, respectively. There was a significant difference between treatments only for average marketable weight and average total weight, in experiment l; the other traits did not differ in either experiment.

\section{Table 5}

Mean values of macro- and micronutrient concentrations in the diagnostic leaf of "Gália" melon grown in a Cambisol and subjected to K:Ca and Mg:Ca cation ratios, at 38 DAS - Experiment II. Mossoró - RN, Brazil, 2020

\begin{tabular}{|c|c|c|c|c|c|c|}
\hline Treatment & $\begin{array}{c}\text { MY } \\
\left(\mathrm{t} \mathrm{ha}^{-1}\right)\end{array}$ & $\begin{array}{c}\text { AMW } \\
(\mathrm{kg})\end{array}$ & $\begin{array}{c}\text { NMF } \\
\text { (un. plt.-1) }\end{array}$ & $\begin{array}{c}\text { TY } \\
\left(\text { t ha-1) }^{-1}\right.\end{array}$ & $\begin{array}{l}\text { ATW } \\
(\mathrm{kg})\end{array}$ & $\begin{array}{c}\text { TNF } \\
\text { (un. plt. }{ }^{-1} \text { ) }\end{array}$ \\
\hline T1 (KOMO) & 19.724 a & $0.928 \mathrm{c}$ & $1.28 \mathrm{a}$ & 23.938 a & $0.810 b$ & 1.78 a \\
\hline T2 (K1M1) & $20.945 \mathrm{a}$ & $1.015 a$ & $1.24 \mathrm{a}$ & 25.557 a & $0.904 a$ & $1.69 a$ \\
\hline T3 (K2M2) & $19.050 \mathrm{a}$ & $1.011 \mathrm{ab}$ & $1.14 \mathrm{a}$ & $22.561 \mathrm{a}$ & 0.888 a & $1.53 \mathrm{a}$ \\
\hline T4 (K2M0) & $20.885 a$ & $0.951 \mathrm{abc}$ & $1.31 \mathrm{a}$ & 23.947 a & $0.843 a b$ & $1.71 \mathrm{a}$ \\
\hline T5 (KOM2) & 23.326 a & $0.953 \mathrm{bc}$ & $1.48 \mathrm{a}$ & $25.491 \mathrm{a}$ & $0.868 \mathrm{ab}$ & $1.77 \mathrm{a}$ \\
\hline CV (\%) & 19.03 & 4.50 & 18.76 & 14.37 & 5.93 & 13.22 \\
\hline
\end{tabular}

MY - marketable yield; AMW - average marketable fruit weight per plant; NMF - number of marketable fruits per plant; TY- total yield; ATW - average total weight per plant; TNF - total number of fruits per plant.

Different letters in the columns indicate significant differences between treatments at $5 \%$ by Tukey's test. 
When each variable was evaluated separately and experiment I was compared with experiment II, the numbers were much higher in the second than in the first experiment, which is explained by the high incidence of whitefly at the end of the cycle in experiment I, which contributed to a significant reduction in production, especially in the second fruit harvest. Upon feeding on the sap, insects cause changes in the vegetative and reproductive development of plants (Hirano, Budiyanto, \& Winarni, 1993), affecting them through the elimination of sugary secretion that induces the appearance of saprophytic fungi that form sooty mold (Campinodium spp.). These can considerably reduce the amount of light that reaches the chlorophyll organs, impairing gas exchange and photosynthesis and, consequently, production (Villas Bôas, França, \& Macedo, 2002).

\section{Table 6}

Mean values for production variables of melon grown in a Cambisol and subjected to different K:Ca and Mg:Ca cation ratios - Experiment II, Mossoró - RN, Brazil, 2020

\begin{tabular}{ccccccc|} 
Treatment & $\begin{array}{c}\text { MY } \\
\left(\mathrm{t} \mathrm{ha}^{-1}\right)\end{array}$ & $\begin{array}{c}\text { AMW } \\
(\mathrm{kg})\end{array}$ & $\begin{array}{c}\text { NMF } \\
(\text { un. plt. }\end{array}$ & $\begin{array}{c}\text { TY } \\
\left(\mathrm{t} \mathrm{ha}^{-1}\right)\end{array}$ & $\begin{array}{c}\text { ATW } \\
(\mathrm{kg})\end{array}$ & $\begin{array}{c}\text { TNF } \\
\text { (un. plt. }\end{array}$ \\
\hline T1 $($ KOM0) & $40.6 \mathrm{a}$ & $1.11 \mathrm{a}$ & $2.20 \mathrm{a}$ & $41.7 \mathrm{a}$ & $1.09 \mathrm{a}$ & $2.32 \mathrm{a}$ \\
T2 (K1M1) & $39.7 \mathrm{a}$ & $1.11 \mathrm{a}$ & $2.16 \mathrm{a}$ & $45.4 \mathrm{a}$ & $1.07 \mathrm{a}$ & $2.57 \mathrm{a}$ \\
T3 (K2M2) & $44.2 \mathrm{a}$ & $1.15 \mathrm{a}$ & $2.31 \mathrm{a}$ & $45.2 \mathrm{a}$ & $1.14 \mathrm{a}$ & $2.39 \mathrm{a}$ \\
T4 (K2M0) & $43.8 \mathrm{a}$ & $1.02 \mathrm{a}$ & $2.57 \mathrm{a}$ & $46.9 \mathrm{a}$ & $0.98 \mathrm{a}$ & $2.86 \mathrm{a}$ \\
T5 (KOM2) & $43.9 \mathrm{a}$ & $1.07 \mathrm{a}$ & $2.47 \mathrm{a}$ & $45.7 \mathrm{a}$ & $1.06 \mathrm{a}$ & $2.60 \mathrm{a}$ \\
CV (\%) & 14.3 & 7.0 & 13.3 & 13.1 & 7.1 & 12.6
\end{tabular}

MY - marketable yield; AMW - average marketable fruit weight per plant; NMF - number of marketable fruits per plant; TY- total yield; ATW - average total weight per plant; TNF - total number of fruits per plant.

Different letters in the columns indicate significant differences between treatments at $5 \%$ by Tukey's test.

In experiment I, marketable yield (Table 5) ranged from 19.05 (K2M2) to 23.32 (KOM2) t ha ${ }^{-1}$, whereas in experiment II (Table 6) this variable varied between 39.7 (K1M1) and 44.2 (K2M2) t ha-1, i.e., an almost twice higher yield. The initial $\mathrm{pH}$ of the soil in experiment II (8.5) was higher than in experiment I (7.5), which may explain the difference between treatments in the different experiments, although at 30 days this $\mathrm{pH}$ had already decreased to close to 7.5. The $\mathrm{pH}$ (potential of hydrogen) of the soil has a direct relationship with fertility and, consequently, with agricultural production and yield. As such it is one of the attributes that most influence plant development, as it is directly linked to the solubility, concentration, availability and retention capacity of most nutrients essential to crops (Lima, Passos e Carvalho, Souza, Costa, \& Montanari, 2016).

Average marketable weight in experiment I (Table 5) differed between treatments, with treatments 2 and 3 showing the highest means and differing from treatment 1 (initial soil condition). Due to their calcareous origin, these soils have a neutral to alkaline $\mathrm{pH}$, which can affect the availability of nutrients for crops. Furthermore, if inadequately 
managed, they can influence development and productivity. In experiment II (Table 6), there was no difference between treatments, with average marketable weight ranging from 1.02 (K2M0) to 1.15 (K2M2) kg fruit ${ }^{-1}$. However, even between the experiments with great difference in production, the average weight differed little, since the production of small fruits is a characteristic of the cultivar.

The number of marketable fruits per plant ranged from 1.14 (K2M2) to 1.48 (KOM2) units plant $^{-1}$ in experiment I (Table 5) and 2.16 (K1M1) to 2.57 (K2M0) units plant ${ }^{-1}$, in experiment II (Table 6). Medeiros, Medeiros, Pereira, Souza and Souza (2011) consider decreases in the number of marketable fruits per plant as the main cause of reduced marketable yield when the salt levels in the water are high.

Total yield (Table 5) ranged from 22.56 (K2M2) to 25.55 (K1M1) t ha-1 in experiment I and from 41.7 (K1M1) to 46.9 (K2M0) t ha-1 in experiment II (Table 6). Total yield means were much lower in experiment I due to whitefly attack.

Average total weight differed between treatments in experiment I (Table 5), where treatment $\mathrm{T} 2$ provided the highest mean $(0.904$ $\mathrm{kg})$, differing from treatments $T 1$ and $T 5$, whose means were 0.810 and $0.868 \mathrm{~kg}$, respectively. The K:Mg:Ca cation ratios of treatments T1 and T5 were 1:3:34 and 1:11:34, respectively, having a higher amount of $\mathrm{Ca}$ relative to the other nutrients ( $\mathrm{K}$ and $\mathrm{Mg}$ ). Calcium, $\mathrm{Mg}$ and $K$ compete for the same uptake site, and the cation at highest concentration in the soil solution has preferential uptake over the others. According to Medeiros et al. (2011), this preferential uptake can cause nutritional imbalance, affecting productivity.
The total number of fruits ranged from 1.53 (K2M2) to 1.78 (KOMO) units plant ${ }^{-1}$ in experiment I (Table 5) and from 2.32 (KOMO) to 2.86 (K2M0) units plant ${ }^{-1}$ in experiment II (Table 6). The lower mean in experiment I is related to whitefly attack as well as lower plant vigor, since less vigorous plants (sources) interfere negatively with the number of fruits (drains) due to the availability of photoassimilates.

\section{Conclusion}

The cation ratios influenced the average marketable and total fruit weights only in experiment $\mathrm{I}$, without affecting yield. Therefore, when associated with irrigation water from the Açu sandstone/Jandaíra limestone aquifer and fertigation, the high absolute $\mathrm{K}$ and medium to high $\mathrm{Mg}$ contents are sufficient to meet the $\mathrm{K}$ and $\mathrm{Mg}$ nutrient requirements, dispensing with correction of the cation ratio.

\section{References}

Anjos, D. C., Hernandez, F. F. F., Costa, J. M. C., Caballero, S. S. U., \& Moreira, V. O. G. (2015) Fertilidade do solo, crescimento e qualidade de frutos do mamoeiro Tainung sob fertirrigação com potássio. Revista Ciência Agronômica, 46(4), 774-785. doi: 10.5935/1806-6690.20150065

Ayers, R.S., \& Westcot, D.W. (1999). A qualidade de água na agricultura (2aed. rev.). (Estudos Irrigação e Drenagem, 29). Campina Grande: UFPB, FAO.

Brady, N. C., \& Weil, R. R. (213). Elementos da natureza e propriedades dos solos (3a ed.). Porto Alegre: Bookman. 
Carmo, F., \& Oliveira, O. F. (1995). Mossoró: um município do semi-árido nordestino, caracterização climática e aspecto florístico. (Coleção Mossoroense, Série B). Mossoró: ESAM.

Crisóstomo, L. A., Santos, A. A., Raij, B., Faria, C. M. B., Silva, D. J., Fernandes, F. A. M.,... Costa, N. D. (2002). Adubação, irrigação, híbridos e práticas culturais para o meloeiro no Nordeste. (Circular Técnica, 14). Fortaleza: EMBRAPA Agroindústria Tropical.

Dias, N. S., Medeiros, J. F., Gheyi, H. R., Silva, F. V., \& Barros, A. D. (2004). Evolução da salinidade de um Argissolo sob cultivo de melão irrigado por gotejamento. Revista Brasileira de Engenharia Agrícola e Ambiental, Campina Grande, 8(2/3), 240246.

Empresa Brasileira de Pesquisa Agropecuária (2017). Manual de análises químicas de solos, plantas e fertilizantes (2a ed.). Brasília, DF: EMBRAPA Informação Tecnológica.

Epstein, E., \& Bloom, A. J. (2006). Nutrição mineral de plantas: princípios e perspectivas. Londrina: Editora Planta.

Hirano, K., Budiyanto, E., \& Winarni, S. (1993). Biological characteristics and forecasting outbreaks of the whitefly, Bemisiatabaci, a vector of virus diseases in soybean fields. Taipei: Food and Fertilizer Technology Center.

Holanda, J. S., Dantas, J. D., Medeiros, A. A., Ferreira, M., Neto, Medeiros, J. F., \& Guedes, F. X. (2017). Indicadores para adubação de culturas em solos do Rio Grande do Norte. (Emparn, Série Documentos, 46). Natal: EMPARN.
Instituto Brasileiro de Geografia e Estatística (2017). Produção agrícola municipal. Recuperado de http://www.ibge.gov.br.

Jakobsen, S. T. (1993). Nutritional disorders between potassium, magnesium, calcium, and phosphorus in soil. Plant and Soil, 154(1), 21-28. doi: 10.1007/978-94-0172496-8_11

Kämpf, A. N. (2005). Preparo do substrato para a produção de plantas ornamentais. In A. N. Kämpf (Ed.), Produção comercial de plantas ornamentais (pp. 45-88). Guaíba: Agropecuária.

Lima, C. G. R., Carvalho, M. P., Souza, A., Costa, N. R., \& Montanari, R. (2016). Correlação entre componentes da produtividade da cana-de-açúcar com pH de um argissolo vermelho distrófico do noroeste paulista. Engenharia na Agricultura, 24(2), 120130. doi: 10.13083/reveng.v24i2.592.

Malavolta, E., Vitti, G. C., \& Oliveira, S. A. (1997). Avaliação do estado nutricional das plantas: princípios e aplicações (2a ed.). Piracicaba: Potafos.

Medeiros, D. C., Medeiros, J. F., Pereira, F. A. L., Souza, R. O., \&Souza, P. A. (2011). Produção e qualidade de melão Cantaloupe cultivado com água de diferentes níveis de salinidade. Revista Caatinga, 24(1), 9298.

Melo, T. K., Medeiros, J. F., Sobrinho, J. E., Figueirêdo, V. B., Pereira, V. C, \& Campos, M. S. (2011). Evapotranspiração e produção do melão Gália irrigado com água de diferentes salinidades e adubação nitrogenada. Revista Brasileira de Engenharia Agrícola e Ambiental, 15(12), 1235-1242. doi: 10.1590/S141543662011001200004 
Moraes, M. S. P., Neto. (2009). Acidez, alcalinidade e efeitos da calagem no solo. Planaltina, DF: Embrapa.

Oliveira, R. C. (2016). Avaliação do aquífero cárstico Jandaíra na região de Baraúna, Rio Grande do Norte. Dissertação de mestrado em Geodinâmica e Geofísica, Universidade Federal do Rio Grande do Norte, Natal, RN, Brasil.

Paiva, A. S., Medeiros, J. F., Silva, M. C. C., Alves, L. P., Sarmento, D. H. A., \& Silva, M. J., Jr., (2004). Salinidade e reação do solo numa área cultivada com melão sob mulch e irrigado com águas de diferentes níveis de sais. Revista Caatinga, Mossoró, 17(2), 57-63.

Santos, H. G., Jacomine, P. K. T., Anjos, L. H. C., Oliveira, V. A., Lumbreras, J. F., Coelho, M. R.,... Cunha, T. J. F. (2018). Sistema brasileiro de classificação de solos. Brasília, DF: Embrapa.

Shen, J., Yuan, L., Zhang, J., Li, H., Bai, Z., Chen, X.,... Zhang, F. (2011). Fósforo Dynamics: do solo para plantar. Plant Physiology, Rockville, 156(3), 997-1005. doi: 10.1104/ pp.111.175232
Silva, J. R. (2000). Efeitos do equilíbrio catiônico do solo na produção e qualidade de frutos de melão (Cucumis melo L.). Dissertação de mestrado em Agronomia, Área de Solos e Nutrição de Plantas, Universidade Federal do Ceará, Fortaleza, CE, Brasil.

Stevens, G., Dunn, D., \& Phipps, B. (2001). How to diagnose soil acidity and alkalinity problems in crops: a comparison of soil $\mathrm{pH}$ test kits. Journal of Extension, 34(4), 1-3.

Taniguchi, C. A. K., Crisostomo, L. A., \& Artur, A. G. (2019). Solos: preparo, nutrição e adubação para o meloeiro. In $\mathrm{M}$. A. Guimarães, \& F. A. S. Aragão (Orgs.), Produção de melão (pp. 122-140). Viçosa, MG: Editora UFV.

Villas Bôas, G. L., França, F. H., \& Macedo, N. (2002). Potencial biótico da moscabranca Bemisia argentifolii a diferentes plantas hospedeiras. Horticultura Brasileira, 20(1), 71-79. doi:10.1590/S01 02-05362002000100014 
